\title{
Interannual variability in temperature and the recruitment of Irish Sea cod
}

\author{
Benjamin Planque*, Clive J. Fox \\ The Centre for Environment Fisheries and Aquaculture Science, Lowestoft Laboratory, Pakefield Road, Lowestoft NR33 0HT, \\ United Kingdom
}

\begin{abstract}
A short review shows that in cold, arctic regions of the North Atlantic positive relationships are generally observed between cod recruitment and water temperatures whilst negative relationships are observed in warm-temperate regions. According to this relationship, cod recruitment in the Irish Sea should be negatively related to sea temperature. Using 3 independent sources of longterm temperature records we test this hypothesis and show a highly significant connection between the recruitment of cod and temperature signals. We suggest that this relationship should be taken into account, in addition to spawning stock biomass, in any future attempt at understanding cod recruitment in this area.
\end{abstract}

KEY WORDS: Cod Temperature - Recruitment - Irish Sea Long-term changes

\section{INTRODUCTION}

Year-to-year variability in temperature has been shown to be linked to changes in fish year-class strength for a number of species (Mysak et al. 1982, Murray et al. 1983, Swartzman et al. 1983, Hansen \& Buch 1986, Jacobson \& MacCall 1995). Atlantic cod Gadus morhua is widely distributed in the waters of the North Atlantic and surrounding seas and occurs in water temperatures in the range -1 to $12^{\circ} \mathrm{C}$. Different stocks show a variety of relationships between recruitment and temperature variations. Three types of response have been reported: firstly a positive link to temperature, this is probably the most widely described relationship (Lablaika et al. 1989, Buch et al. 1994, Malmberg \& Blindheim 1994, Ottersen et al. 1994, Ottersen \& Sundby 1995, Ottersen 1996); secondly, a negative response which has been reported in a few cases (Martin \& Kohler 1965, Dickson et al. 1973); and thirdly an absence of linkage between temperature and recruitment (Serchuk et al. 1993, Hansen et al. 1994, Heessen \& Daan 1994). Ottersen (1996) summarised these relationships in relation to different

•E-mail: b.planque@cefas.co.uk water masses and showed that positive relationships are usually found in cold northern waters, negative relationships in more southerly warm waters and an absence of relationship occurs at intermediate temperatures (Fig. 1).

In the Irish Sea, the maximum intensity of cod spawning has been reported from early March to April (Brander 1994), with the highest concentration of eggs being found in the western Irish Sea, although significant numbers have also been recorded in the eastern Irish Sea (Nichols et al. 1993, Fox et al. 1997). In the western area, cod larvae hatch in the coastal waters off the Irish coast but are found in deeper offshore regions by late spring and early summer (Dickey-Collas et al. 1996). The offshore circulation in this area is characterised by a density-driven gyre which develops during the spring and persists throughout the summer season. The distribution patterns of young cod in this region are probably linked to the onset of this recurrent hydrographic feature (Hill et al. 1994, Dickey-Collas et al. 1996, 1997, Hill et al. 1996). The Irish Sea is towards the southern boundary of the geographical range of the species, although cod do occur further south in the Celtic Sea. Based on the concept presented in Fig. 1 and linking recruitment and water 


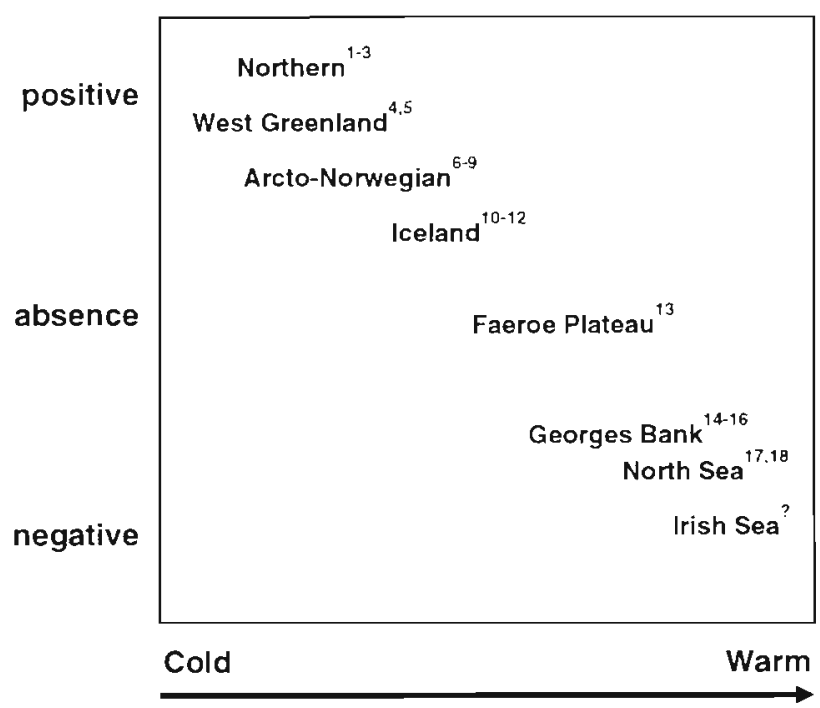

Temperature

Fig. 1. A schematic representation of the nature of the relationship between temperature changes and recruitment for different North Atlantic cod stocks. A positive effect (cod recruitment is favoured during warmer years) is generally observed in cold waters whereas a negative effect (cod recruitment is favoured during colder years) is found in warm waters, drawn from Ottersen (1996). References to each stock are as follows: ${ }^{1}$ Elizarov (1963), ${ }^{2}$ deYoung \& Rose (1993), ${ }^{3}$ Taggart et al. (1994), ${ }^{4}$ Hermann (1953), ${ }^{5}$ Buch et al. (1994), ${ }^{6}$ Izhevskii (1964), ${ }^{7}$ Satersdal \& Loeng $(1987),{ }^{8}$ Ottersen et al. (1994), ${ }^{9}$ Ottersen \& Sundby (1995), ${ }^{10}$ Malmberg (1986), ${ }^{11}$ Malmberg \& Blindheim (1994), ${ }^{12}$ Astthorsson et al. (1994), ${ }^{13}$ Hansen et al. (1994), ${ }^{14}$ Martin \& Kohler (1965), ${ }^{15}$ Holzwarth \& Mountain (1992), ${ }^{16}$ Serchuk et al. (1993), ${ }^{17}$ Dickson et al. (1973), ${ }^{18}$ Svendsen et al. (1995)

temperature, we should expect a negative relationship for the Irish Sea. Appropriate temperature datasets for the coastal region of the western Irish Sea with which to examine this relationship have not been collected in the past. Hence, in the present paper we study this relationship using available temperature data from 3 different sources: hindcasts from a physical model driven by local meteorological data, a time-series derived from coarse long-term datasets (the Comprehensive Ocean Atmosphere DataSet and the Reynolds SST dataset) and a local time-series collected by the Port Erin Marine Laboratory (Isle of Man).

\section{DATA AND METHOD}

Cod recruitment. The estimates of cod recruitment at age 0 are from tuned Virtual Population Analysis (VPA) on catch and research data for ICES area VIIa, for the period 1968 to 1996 . VPA tuning data from the commercial fisheries were available for the UK fleet. A total of 7 research vessel surveys with 4 or more years

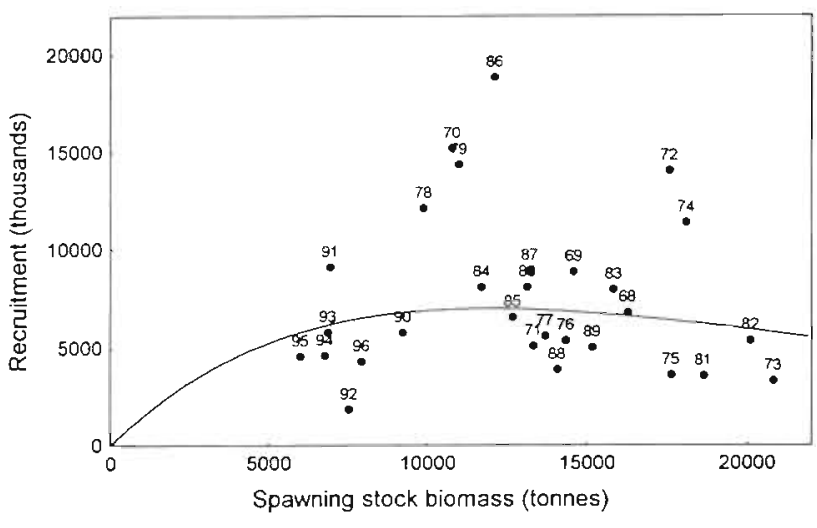

Fig. 2. Recruitment of Irish Sea cod plotted against spawning stock biomass (dots) and associated Ricker fit (line). The Ricker model is: $\operatorname{Rec}=\mathrm{SSB} \cdot \mathrm{e}^{(0.468-0.000064 \mathrm{SSB})}$

of data were available for inclusion in the tuning procedure, including direct estimates on recruitment lage 0 group). Annual numbers of cod recruits were estimated following the procedure of the ICES Working Group on the Assessment of Northern Shelf Demersal Stocks (Anonymous 1997). Fig. 2 shows the stockrecruitment scatter plot and the associated Ricker fit (Ricker 1954). It is well documented (e.g. Myers \& Barrowman 1996) that recruitment can be strongly affected by changes in spawning stock biomass (SSB), especially when SSB is particularly low. However, for the stock levels observed during the period of study, the Ricker fit shows an almost flat relationship between stock and recruitment. Therefore recruitment data were considered independently from SSB.

Model hindcast. A hindcast of the sea surface temperature (SST) for the western Irish Sea region $\left(6^{\circ}\right.$ to $5^{\circ} \mathrm{W}$ and $53.5^{\circ}$ to $54.5^{\circ} \mathrm{N}$ ) was derived from the physical model of Prestidge \& Taylor (1995). The 1-dimensional stratification model was implemented on a $5 \mathrm{~km}$ grid and forced with hourly meteorological data from Dublin airport and the resulting SST estimates output for every $4 \mathrm{~h}$. Due to limitations in the accuracy of SST estimates during the summer period in stratified areas, surface temperatures were extracted up to mid-May only. Data were averaged over weekly periods from Julian day 42 to 140 for each year from 1966 to 1994

COADS and Reynolds SST. The Comprehensive Ocean Atmosphere DataSet (COADS; Woodruff et al. 1987) is a global oceanographic dataset which includes a statistical summary of SST for each month of each year using $2^{\circ}$ latitude $\times 2^{\circ}$ longitude boxes. The exact positions of samples collected in the Irish Sea could not be derived but samples were more abundant in the eastern and southern parts of the Irish Sea than in the western Irish Sea. The data for each month of each year were interpolated by kriging and the resulting 
temperature estimates averaged for the period January to December of each year from 1966 to 1992. The Reynolds temperature dataset (Reynolds 1988) is a monthly statistical summary of SST month using $1^{\circ}$ latitude $\times 1^{\circ}$ longitude boxes based on similar data as in COADS with additional estimations from satellite imagery. Temperature estimates from the Reynolds dataset were used from January 1981 to December 1996. After checking for bias in the average temperature estimates for the period 1981 to 1992 when the 2 datasets overlap, the 2 series were merged to produce a time-series from January 1966 to December 1996.

Port Erin temperature. Data on temperature have been collected weekly since 1954 off Port Erin Bay at Cypris station $\left(54^{\circ} 05^{\prime} 30^{\prime \prime} \mathrm{N}, 4^{\circ} 50^{\prime} 00^{\prime \prime} \mathrm{W}\right)$ for 5 depths. Surface temperatures $(0 \mathrm{~m})$ which allowed comparison with SST derived from the modelled temperature or COADS were extracted for the period 1966 to 1996. A value was derived for each month for the period January to December of each year from 1966 to 1996 using spline interpolation.

Time-series analysis. The 3 temperature time-series relate to different areas in the Irish Sea and the modelled SST is calculated over a short period of the year. Therefore, the average absolute temperature values vary between the series. To correct for these differences, we derived from each temperature time-series a series of temperature anomalies calculated as the departure from the mean value for the period of reference 1966 to 1994. The comparison of temperature anomaly and recruitment time-series was then carried out using correlation analysis. The non-parametric Spearman's rank correlation coefficient was used for all comparisons. No significant $(p>0.05)$ autocorrelation was detected in the series, and hence no correction was made either on the raw data or on the number of degrees of freedom when evaluating the significance of correlation coefficients.

Table 1. Spearman's rank correlation coefficients between the time-series of temperature derived from the model of Prestidge \& Taylor (1995), the COADS and Reynolds dataset and Port Erin survey, and cod recruitment from ICES VPA.

( . Indicates a probability of type 1 error of $1 \%$ )

\begin{tabular}{|lccc|}
\hline & $\begin{array}{c}\text { Modelled } \\
\text { temperature }\end{array}$ & $\begin{array}{c}\text { COADS/ } \\
\text { Reynolds } \\
\text { temperature }\end{array}$ & $\begin{array}{c}\text { Cypris } \\
\text { station } \\
\text { temperature }\end{array}$ \\
\hline COADS/Reynolds & $0.64 *$ & - & - \\
temperature & $\mathrm{n}=28$ & & \\
Cypris station & $0.70^{*}$ & $0.64^{*}$ & - \\
temperature & $\mathrm{n}=28$ & $\mathrm{n}=31$ & \\
Cod recruitment & $-0.66^{*}$ & $-0.64 \cdots$ & $-0.63 \cdot$ \\
& $\mathrm{n}=26$ & $\mathrm{n}=29$ & $\mathrm{n}=29$ \\
& & & \\
\hline
\end{tabular}

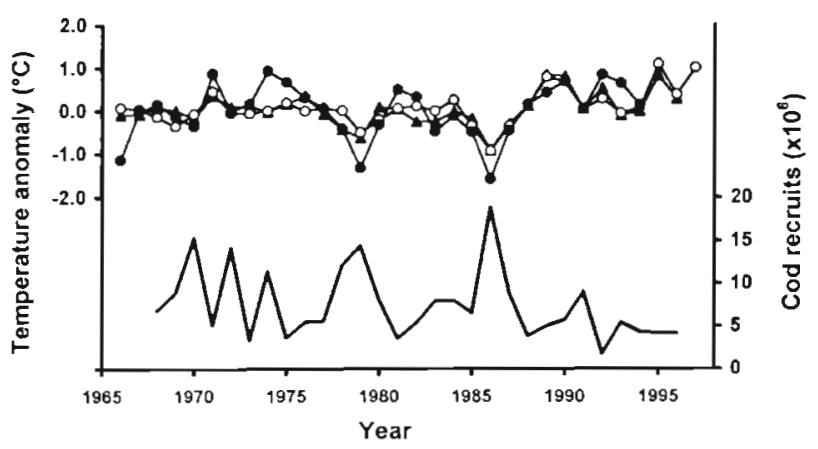

Fig. 3. Time-series of cod recruitment (plain line) in the Irish Sea derived from virtual population analysis (VPA), anomalies in sea surface temperature (from mid-February to midMay) in the western Irish Sea estimated from the model of Prestidge \& Taylor (1995) ( $\bullet$ ), anomalies in mean annual sea surface temperature in the Irish Sea from the COADS and Reynolds SST datasets (O) and anomalies in mean annual sea surface temperature at Port Erin Cypris station ( $\mathbf{\wedge})$

\section{RESULTS}

Fig. 3 shows the year-to-year changes in cod recruitment and anomalies in sea surface temperature (SST) derived from the model, COADS dataset and Port Erin Cypris station datâ. The 3 SST time series show similar profiles which are characterised by a period of average temperatures during 1971 to 1977,2 minima in 1979 and 1986 and an increase in temperature in 1989-90, 1992 and 1995. There is a high degree of similarity between all 3 temperature series as shown by the significant correlation coefficients between them (Table 1). The cod recruitment time series shows high variability with values ranging from 1.8 to $18 \times 10^{6}$ recruits $\mathrm{yr}^{-1}$. The changes in recruitment are opposite to those in the temperature signal with years of negative temperature anomaly generally matching years of high recruitment (e.g. 1979 and 1986) and vice-versa (e.g. 1981-82, 1988-89, 1994). The correlation between temperature and cod recruitment is significant regardless of which temperature time-series is used (Table 1). The highest correlation is found with temperature output from the physical model. This is the only temperature estimate for the western Irish Sea area alone, where cod eggs and larvae are found in high abundance. The negative correlations between changes in temperature and cod recruitment are made clear in Fig. 4. This relationship is consistent with results from published studies if they are interpreted as in Fig 1.

\section{DISCUSSION}

There are many possible mechanisms which might lead to a link between cod recruitment and tempera- 


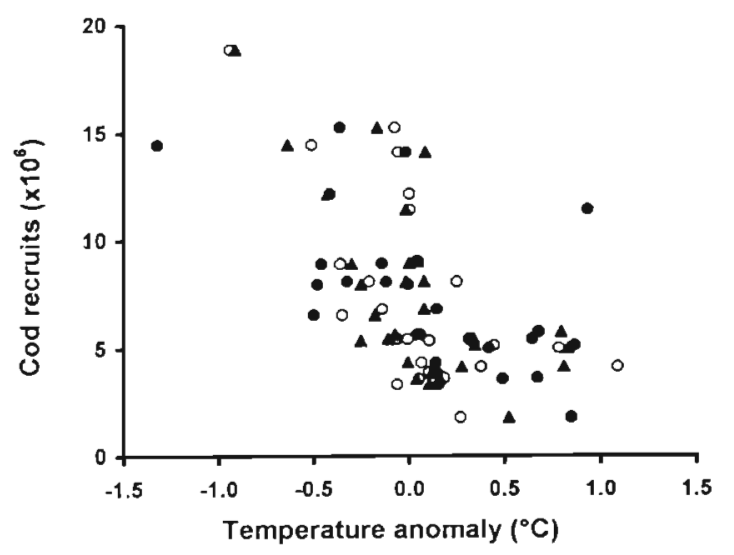

Fig. 4. Number of cod recruits plotted against modelled SST (•). COADS/Reynolds SST (0), and Port Erin Cypris station SST ( $\bullet$

ture. Off Newfoundland, deYoung \& Rose (1993) observed that changes in temperature were associated with latitudinal displacement of the cod stock between favourable and less favourable spawning sites. Ellertsen et al. (1989) and Nakken (1994) observed that the timing of spawning of Arctic cod is fixed while the spawning of Calanus finmarchicus (the main prey for cod larvae) can vary by up to 6 wk between a cold and a warm year, inducing mismatches in extremely cold or warm years. Conversely, Hutchings \& Myers (1994) showed that off Newfoundland the spawning time of cod not only varies between regions, but also between years. The differences in peak spawning times were up to $90 \mathrm{~d}$ and these variations were partially attributed to year-to-year fluctuations in temperature $(-1.7$ to $-0.9^{\circ} \mathrm{C}$ ). It was suggested that low winter temperatures have a negative influence on gonad development and delay the onset of spawning in this stock. Similar conclusions were drawn by Kjesbu (1994) who reported that a $1^{\circ} \mathrm{C}$ drop in temperature during vitellogenesis would delay spawning by about 8 to $10 \mathrm{~d}$ (from results at $9^{\circ} \mathrm{C}$ ). Increased temperatures have also been reported to affect the degree and timing of oocyte maturation and ovulation in the warmwater Pacific cod (Tyler 1995) as well as egg viability and fertility in other species (Howell \& Scott 1989, Flett et al. 1996). In the present study, the range of temperatures between the coolest and warmest years was around $3^{\circ} \mathrm{C}$. This range should be sufficient to induce similar effects to those reported above. The mechanism linking temperature and cod recruitment in the Irish Sea could therefore be due to direct effects on the reproductive biology of fish, effects on the physiology of eggs and/or larvae, influence of temperature upon food production or a combination of the three. It is not currently possible to define a mechanism for the link between tem- perature and cod recruitment in the Irish Sea, and the observed relationship needs to be supported by independent analyses and observations. However, this previously unreported connection is so strong that it should be considered, in addition to SSB, in any future attempts at understanding cod recruitment in the Irish Sea.

Acknowledgements. The authors acknowledge the hard work of all those scientists who have contributed to the development of the long-term data series used in this study. The authors are greatly indebted to Richard Nash at Port Erin Laboratory (Liverpool University) for providing the Cypris station temperature data, Steve Worley (National Center for Atmospheric Research) for providing the COADS data, and Arnold H. Taylor (Plymouth Marine Laboratory) for providing the stratification model output. This work was funded by MAFF under program MF0420, Physical and Biological Controls on Fish Stocks.

\section{LITERATURE CITED}

Anonymous (1997) Report of the working group on the assessment of northern shelf demersal stocks. ICES (Copenhagen) ICES Comm Meet 1997/Assess: 2

Astthorsson OS, Gislason A, Gudmundsdottir A (1994) Distribution, abundance, and length of pelagic juvenile cod in Icelandic waters in relation to environmental conditions. ICES Mar Sci Symp 198:529-541

Brander KM (1994) The location and timing of cod spawning around the British Isles. ICES J Mar Sci 51:71-89

Buch E, Horsted SA, Hovgård H (1994) Fluctuations in occurrence of. cod in the Greenland waters and their possible causes. ICES Mar Sci Symp 198:158-174

deYoung $B$, Rose GA (1993) On recruitment and distribution of Atlantic cod (Gadus morhua) off Newfoundland. Can J Fish Aquat Sci 50:2729-2741

Dickey-Collas M, Brown J, Fernand L, Hill AE, Horsburgh KJ, Gravine RW (1997) Does the western Irish Sea gyre influence the distribution of pelagic juvenile fish? J Fish Biol 51:206-229

Dickey-Collas M, Gowen RJ, Fox CJ (1996) Distribution of larval and juvenile fish in the western Irish Sea: relationship to phytoplankton, zooplankton biomass and recurrent physical features. Mar Freshwat Res 47:169-181

Dickson RR, Pope JG, Holden MJ (1973) Environmental influence on the survival of North Sea cod. In: Blaxter JHSE (ed) The early life history of fish. Springer-Verlag, Heidelberg, p 69-80

Elizarov AA (1963) On oceanographic conditions influencing year-class strength of commercially important species in the Northwest Atlantic. Oceanology 3:106.j-1078

Ellertsen B, Fossum P, Solemdal P. Sundby S (1989) Relation between temperature and survival of eggs and first-feeding larvae of Northeast Arctic cod (Gadus morhua L.). Rapp PV Réun Cons Int Explor Mer 191:209-219

Flett PA, Munkittrıck KR, Van Der Kraak G, Leatherland JF (1996) Overripening as the cause of low survival to hatch in Lake Erie coho salmon (Oncorhynchus kisutch) embryos. Can J Zool 74:851-857

Fox CJ, Dickey-Collas M, Winpenny AJ (1997) Spring plankton surveys of the Irish Sea in 1995: the distribution of fish eggs and larvae. The Centre for Environment Fisheries and Aquaculture Science (Lowestoft) Science series, Technical Report 104 
Hansen H, Buch E (1986) Prediction of year-class strength of Atlantic cod (Gadus morhua) off West Greenland. NAFO Sci Counc Stud 10:7-11

Hansen B, Gaard E, Reinert J (1994) Physical effects on recruitment of Faroe Plateau cod. ICES Mar Sci Symp 198: $520-528$

Heessen HJL, Daan N (1994) Cod distribution and temperature in the North Sea. ICES Mar Sci Symp 198:244-253

Hermann F (1953) Influence of temperature on strength of cod year-class. Ann Biol 9:1-31

Hill AE, Brown J, Fernand L (1996) The western Irish Sea gyre: a retention system for Norway lobster (Nephrops norvegicus)? Oceanol Acta 19:357-368

Hill AE, Durazo R, Smeed DA (1994) Observations of a cyclonic gyre in the western Irish Sea. Cont Shelf Res 14: $479-490$

Holzwarth T, Mountain D (1992) Surface and bottom temperature distribution from the Northeast Fisheries Center spring and fall trawl survey program, 1963-1987, with addendum for 1988-1990. Northeast Fisheries Science Center, Woods Hole, MA, Ref Doc 90-03

Howell BR, Scott AP (1989) Ovulation cycles and post-ovulatory deterioration of eggs of the turbot (Scophthalmus maximus L.). Rapp PV Réun Cons Int Explor Mer 191: $21-26$

Hutchings JA, Myers RA (1994) Timing of cod reproduction: interannual variability and the influence of temperature. Mar Ecol Prog Ser 108:21-31

Izhevskii GK (1964) Forecasting of oceanological conditions and the reproduction of commercial fish. Transl 1966: Israel Prog Sci Transl, Jerusalem

Jacobson LD, MacCall AD (1995) Stock-recruitment models for Pacific sardine (Sardinops sagax). Can J Fish Aquat Sci $52: 566-577$

Kjesbu OS (1994) Time of start of spawning in Atlantic cod (Gadus morhua) females in relation to vitellogenic oocyte diameter, temperature, fish length and condition. J Fish Biol 45:719-735

Lablaika IA, Hoziosky SA, Kalejs M (1989) Abundance dynamics of eastern Baltic cod stocks and related factors. Rapp PV Réun Cons Int Explor Mer 190:163-165

Malmberg SA (1986) Ecological impact of hydrographic conditions in Icelandic waters. In: Wyatt $T$, Larrañeta (eds) Int symp long term changes mar fish pop. Vigo, p 95-123

Malmberg SA, Blindheim J (1994) Climate, cod, and capelin in northern waters. ICES Mar Sci Symp 198:297-310

Martin WR, Kohler AC (1965) Variations in recruitment of cod (Gadus morhua L.) in southern ICNAF waters, as related to environment changes. ICNAF Spec Pub 6:833-846

Murray T, LeDuc S, Ingham M (1983) Impact of climatic factors on early life stages of Atlantic mackerel, Scomber scombrus, L.: an applications of meteorological data to a fishery problem. J Clim Appl Meteorol 22:57

Myers RA, Barrowman NJ (1996) Is fish recruitment related to spawners abundance? Fish Bull 94:707-724

Mysak LA, Hsieh WW, Parsons TR (1982) On the relationship

Editorial responsibility: Otto Kinne (Editor),

Oldendorf/Luhe, Germany between interannual baroclinic waves and fish populations in the Northeast Pacific. Biol Oceanogr 2:63-103

Nakken $O$ (1994) Causes of trends and fluctuations in the Arcto-Norwegian cod stocks. ICES Mar Sci Symp 198: 212-228

Nichols JH, Haynes GM. Fox CJ, Milligan SP, Brander KM, Chapman RJ (1993) Spring plankton surveys of the Irish Sea in 1982, 1985, 1987, 1988 and 1989: hydrography and the distribution of fish eggs and larvae. Directorate of Fisheries Research (Lowestoft), Fisheries Research Technical Report 95

Ottersen G (1996) Environmental impact on variability in recruitment, larval growth and distribution of Arcto-Norwegian cod. $\mathrm{PhD}$, University of Bergen

Ottersen G, Loeng H, Raknes A (1994) Influence of temperature variability on recruitment of cod in the Barents Sea. ICES Mar Sci Symp 198:471-481

Ottersen G, Sundby S (1995) Effects of temperature, wind and spawning stock biomass on recruitment of Arcto-Norwegian cod. Fish Oceanogr 4:278-292

Prestidge MC, Taylor A.H (1995) A modelling investigation of the distribution of stratification and phytoplankton abundance in the Irish Sea. J Plankton Res 17:1397-1420

Reynolds RW (1988) A real-time global sea surface temperature analysis. J Clim 1:75-86

Ricker WE (1954) Stock and recruitment. J Fish Res Bd Can 11:559-623

Sætersdal G, Loeng H (1987) Ecological adaptation of reproduction in Northeast Arctic cod. Fish Res 5:253-270

Serchuk FM, O'Brien L, Mayo RK, Wigley SE (1993) Assessment of the Georges Bank cod stock for 1992. Northeast Fisheries Science Center, Woods Hole, MA, Ref Doc 93-05

Svendsen $E$, Aglen A, Iversen SA, Skagen DW, Smestad O (1995) Influence of climate on recruitment and migration of fish stocks in the North Sea. In: Beamish RJ (ed) Climate change and northern fish populations. Can Spec Pub Fish Aquat Sci 121:641-653

Swartzman GL, Gertz WM, Francis RC, Haar RT, Rose KA (1983) A management analysis of the Pacific whiting (Merluccius productus) fishery using an age-structured stochastic recruitment model. Can J Fish Aquat Sci 40 : $524-539$

Taggart CT, Anderson J, Bishop CA, Colbourne E, Hutchings JA, Lilly G, Morgan J, Murphy E, Myers RA, Rose GA, Shelton P (1994) Overview of cod stocks, biology, and environment in the Northwest Atlantic region of Newfoundland, with emphasis on northern cod. ICES Mar Sci Symp 198:140-157

Tyler AV (1995) Warmwater and cool-water stocks of Pacific cod (Gadus macrocephalus): a comparative study of reproductive biology and stock dynamics. In: Beamish RJ (ed) Climate change and northern fish population. Can Spec Pub Fish Aquat Sci 121:537-545

Woodruff SD, Slutz RJ, Jenne RL, Steurer PM (1987) A comprehensive ocean-atmosphere dataset. Bull Am Meteor Soc 68:1239-1250

Submitted: March 11, 1998; Accepted: August 3, 1998

Proofs received from author(s): September 22, 1998 